\title{
Role of Forest Resources to Local Livelihoods: The Case of East Mau Forest Ecosystem, Kenya
}

\author{
D. K. Langat, ${ }^{1}$ E. K. Maranga, ${ }^{2}$ A. A. Aboud, ${ }^{2}$ and J. K. Cheboiwo ${ }^{3}$ \\ ${ }^{1}$ Kenya Forestry Research Institute, P.O. Box 5199, Kisumu 40108, Kenya \\ ${ }^{2}$ Department of Natural Resources, Egerton University, P.O. Box 536, Njoro 20115, Kenya \\ ${ }^{3}$ Kenya Forestry Research Institute, P.O. Box 20412, Nairobi 00200, Kenya
}

Correspondence should be addressed to D. K. Langat; dkipkirui@yahoo.com

Received 11 November 2015; Accepted 3 February 2016

Academic Editor: Piermaria Corona

Copyright (C) 2016 D. K. Langat et al. This is an open access article distributed under the Creative Commons Attribution License, which permits unrestricted use, distribution, and reproduction in any medium, provided the original work is properly cited.

\begin{abstract}
Forests in Kenya are threatened by unsustainable uses and conversion to alternative land uses. In spite of the consequences of forest degradation and biodiversity loss and reliance of communities on forests livelihoods, there is little empirical data on the role of forest resources in livelihoods of the local communities. Socioeconomic, demographic, and forest use data were obtained by interviewing 367 households. Forest product market survey was undertaken to determine prices of various forest products for valuation of forest use. Forest income was significant to households contributing 33\% of total household income. Fuel wood contributed $50 \%$, food $(27 \%)$, construction material (18\%), and fodder, and thatching material 5\% to household forest income. Absolute forest income and relative forest income (\%) were not significantly different across study locations and between ethnic groups. However, absolute forest income and relative forest income (\%) were significantly different among wealth classes. Poor households were more dependent on forests resources. However, in absolute terms, the rich households derived higher forest income. These results provide valuable information on the role of forest resources to livelihoods and could be applied in developing forest conservation policies for enhanced ecosystem services and livelihoods.
\end{abstract}

\section{Introduction}

Forests are important in the livelihoods of local people in most developing countries. Local people depend on forests resources for various products such as fuel wood, construction materials, medicine, and food. Globally, it is estimated that between 1.095 billion and 1.745 billion people depend to varying degrees on forests for their livelihoods and about 200 million indigenous communities are almost fully dependent on forests [1]. Moreover, 350 million people who live adjacent to dense forests depend on them for subsistence and income $[1,2]$. It is estimated that $20-25 \%$ of rural peoples' income is obtained from environmental resources in developing countries [3] and act as safety nets in periods of crisis or during seasonal food shortages $[4,5]$. Deforestation and degradation of forest ecosystems, in Kenya, is widely acknowledged and, despite the widespread degradation, there is dearth of quantitative information on the role of forest resources to livelihoods and dependence to guide sustainable use. This paper analyzed the role of forest resources in local livelihoods and determined the forest dependence in East Mau forest ecosystem, Kenya.

\section{Materials and Methods}

2.1. Study Site. This study was undertaken in East Mau Forest situated about $50 \mathrm{~km}$ south of Nakuru Town at $35^{\circ} 58^{\prime} 00^{\prime \prime} \mathrm{E}$ and $00^{\circ} 32^{\prime} 00^{\prime \prime} \mathrm{S}$, altitude range of 1200 and $2600 \mathrm{~m}$ (Figure 1). It has an area of approximately $280 \mathrm{~km}^{2}$ and has the highest number of indigenous forest dwellers-the Ogiek community. East Mau forest forms an important watershed within the Mau Forest Complex, feeding major rivers and streams that make up the hydrological systems of Lake Victoria and inland Lakes of Nakuru, Baringo, and Natron. The forest is home to endangered mammals like the yellow-backed duiker (Cephalophus sylvicultor) and the African golden cat (Felis aurata) and other important fauna such as Giant Forest Hog, Gazelle, Buffalo, Leopard, Hyena, Antelope, Monkey, and 


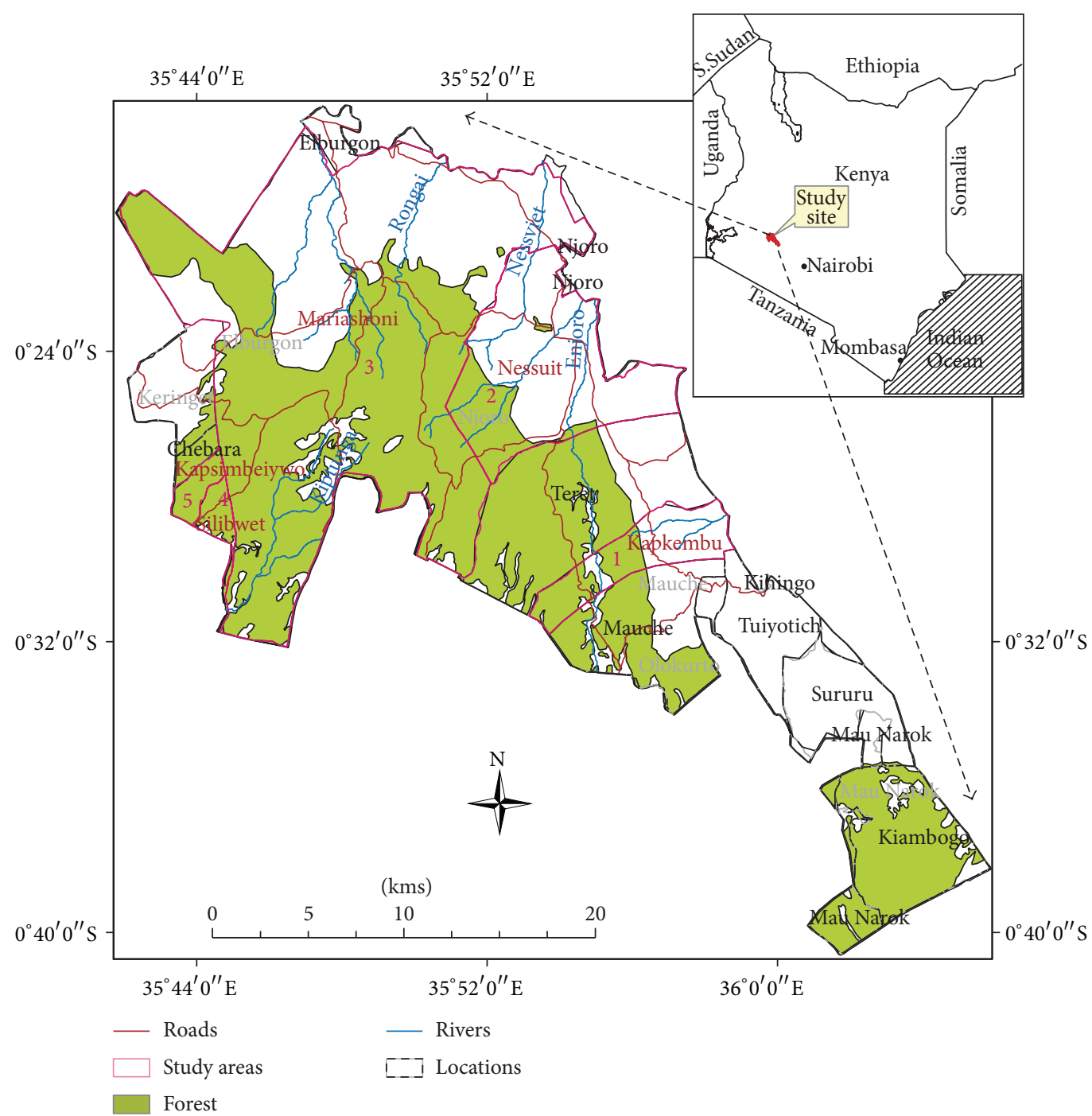

FIgURE 1: Map of the study area in East Mau forest in Kenya.

small animals like the Giant African Genet, Tree Hyrax, and Honey badger [6]. This makes the forest ecosystem an important resource base for the local communities and national and international community. The total forest area was originally about 66,000 ha but more than half of it was excised for human settlement in 2001 [7].

The area is comprised of the escarpments, hills, rolling land, and plains with slopes ranging from $2 \%$ in the plains to more than $30 \%$ in the foothills and geological studies have shown that the area is mainly composed of quaternary and tertiary volcanic deposits [8]. In the lowlands, the top soils are of mainly clay loam (CL) to loam (L) in texture and the subsoil texture ranges from silty clay loam (SCL) to clay loam (CL) and clay $(\mathrm{C})$, with $\mathrm{pH}$ values ranging from 5.6 to 6.4 , making them slightly to moderately acidic in nature [9]. In the lowland, Luvisol, Vertisol, Planosol, Cambisol, and Solonetz soils from the Holocene sedimentary deposits are primarily prevalent and occur in saline and sodic phases. In the upland areas, however, the soils have a high content of silt and clay predominantly Ferrasols, Nitisols, Cambisols, and Acricsols [9]. The adjoining settlements have gentle slopes with deepfertile-volcanic soils which are suitable for maize, wheat, potatoes, horticultural crops, and livestock keeping [10].

The climate is characterized by a trimodal precipitation pattern with the long and intense rains from April to June; short rains in August; and shorter, less intense rains from November to December with mean monthly rainfall between $30 \mathrm{~mm}$ and $120 \mathrm{~mm}$ and total annual precipitation of $1200 \mathrm{~mm}$. The mean annual temperatures are in the range of 12 to $16^{\circ} \mathrm{C}$, with greatest diurnal variation during the dry season [11].

2.2. Data Collection. Household data was collected from respondents from the month of January to May 2013 and September to December 2013. All households within and adjacent to East Mau forest totaling 43,257 households from 17 administrative units (locations) [12] constituted the research population. Five administrative units were selected 
in consultation with local administrative officials using two main criteria: age of settlement and ethnic composition of residents. The following administrative locations were selected: Mariashoni representing an old settlement predominantly occupied by Ogiek indigenous community, Kapkembu-representing a recent settlement with a homogenous community of the Kipsigis, Nessuit-representing a recent settlement with a heterogeneous population of indigenous and immigrant ethnic groups and Kapsimbeiywo, and Silibwet-representing a relatively old settlement with a homogenous community of the Kipsigis community.

Study villages in all the five locations were randomly selected from the list of villages provided by local administrative officials and village elders. Respondent households from each village were randomly selected from detailed households' lists (with names of household head and assigned numbers for use in random sampling). In polygamous unions, households were listed according to the wife's name and each considered a separate household. The simple size for each study village and location was determined using the most recent national census data [12] and applying the method by O. Mugenda and A. Mugenda [13]. In total 367 households were selected for the study. Sociodemographic data were collected using structured and semistructured questionnaires. To improve the confidence of the respondents and quality of data, local trained research assistants conversant with local languages interviewed the respondents in the presence of village elders. In most cases, the head of the household was interviewed and, in the absence, the wife or the eldest son was interviewed. The following socioeconomic data were collected from each household: sources of cash income, resources endowment (land size, livestock size, and physical assets), literacy levels (education level), household size, resident years, ethnicity, and distance from the forest. Forest utilization data included consumption patterns of forest products (including their sources, average quantity per month, and household monthly consumption), collection and type of forest products, and other associated information. The information obtained from respondents was triangulated using key informants and focus group discussions.

The market survey captured the prices of various forest products traded in local markets and prices used to value the household forest-product consumption and determined monetary contribution of the forest products to the total household income.

2.3. Data Analysis. The collected field data were compiled and analyzed using the statistical package IBM SPSS version 21 (2013) and Microsoft Office Excel 2010. The household incomes were calculated without accounting for local labour costs because of substantial variation in costs for each activity and the possibility of multiple tasks by households [14]. The household incomes were computed using the formulae (1) to (4) as shown below.

Household annual income $=($ forest Income + agriculture income + return to wealth + wage income):

$$
Y_{\text {tinc }}=\sum_{i=1}^{n}\left[s_{i}\right] \text {, }
$$

where $Y_{\text {tinc }}$ is total household income and $s_{i}$ is income source I.

Forest income $=($ fuel wood annual income + wild fruits income + poles income + thatching grass income and forest grazing, etc.):

$$
Y_{f}=\sum_{i=1}^{n}\left[F_{i} P_{i}-\left(K_{i}\right)\right]
$$

where $Y_{f}$ is total forest income, $F_{i}$ is quantity of product collected $I, P_{i}$ is market price of forest product $I$, and $K_{i}$ is production costs of forest product $i$.

The value of forest grazing was estimated by substitute approach (the Appendix).

Crop income: this was summation of value of yield from various crops grown by a household less all costs of production. Total crop income was calculated as

$$
Y_{c}=\sum_{i=1}^{n}\left[C_{i} P_{i}-\left(K_{i}\right)\right]
$$

where $Y_{c}$ is total crop income, $C_{i}$ is yield of crop $I, P_{i}$ is market price of crop $I$, and $K_{i}$ is production costs of crop $i$.

Livestock income $=($ cattle sale income + goats income + sheep income + donkeys income + chicken income) + income from livestock products that is

$$
Y_{l}=\sum_{i=1}^{n}\left[N_{i} P_{i}-\left(K_{i}\right)\right]+\sum_{i=1}^{n}\left[Q_{i} P_{i}-\left(K_{i}\right)\right],
$$

where $Y_{l}$ is total livestock income, $N_{i}$ is number of livestock in category $I, Q_{i}$ is quantity of product from livestock $I, P_{i}$ is market price of livestock $I$, and $K_{i}$ is cash costs of keeping livestock $i$, like pay for herder, costs of medicines, feeds.

Income from off-farm income/employment: this was the total value of earnings through hiring out of labour on other households' lands for agricultural or any other economic activity.

2.3.1. Statistical Tests. Socioeconomic data presents a challenge in a heterogeneous community where extreme income values from individual households are expected. Data was subjected to normality tests (box-plot, histogram). All the identified outliers in the data set were removed to conform to normal distribution. It was then that parametric tests (analysis of variance (ANOVA)) were applied [15]. In all statistical tests, $p \leq 0.05$ level of significance was used. Tests were conducted on socioeconomic characteristics, $\chi^{2}$ test being for association of locations and sources of forest products, wealth, education level, and ethnicity. Comparison of means and one-way ANOVA were used to test the difference on forest incomes, relative forest incomes on locations, ethnicity, and wealth class and separation of means undertaken using Tukey B.

2.3.2. Measuring Forest Dependence. The forest dependence was measured using the relative forest income. Relative forest income (RFI) was computed as a share of net forest income to 
total household income accounts derived from consumption and sale of forest environmental resources. This was derived as

$$
\mathrm{RFI}=\frac{\mathrm{TFI}}{\mathrm{TI}},
$$

where TI is the total household income and TFI is total forest environmental income.

To test the level of forest dependence of income groups, sampled households were categorized into 3 income groups based on their level of total households income in Kenya Shillings: Poor, 0-156,000, Moderately Poor, 156001-270,000, and Rich, $>271,000$. The categories were based on local conditions and do not reflect the general poverty levels in the study area and Kenya.

\section{Results}

3.1. Socioeconomic and Demographic Characteristics of Households. The gender distribution of household heads showed that $62.6 \%(n=243)$ were males while $37.4 \%(n=145)$ were females. The mean age of household head was significantly different $(p<0.001)$ for female $(53.35 \pm 1.9)$ and male-headed households $(47.56 \pm 1.2)$. The majority of the respondents in the Kapsimbeiywo and Silibwet location were immigrants (100\%) while in Nessuit there was an equal presence of indigenous (Ogiek-50\%) and nonindigenous people (50\%). In Mariashoni and Nessuit, the majority of households were of Ogiek tribe (65\%) and Nessuit (50\%). In Kapkembu, the area was inhabited mostly by nonindigenous group of Kipsigis $(92.5 \%)$ and a small proportion of Ogiek at 7.5\% (Table 1 ).

The majority of households were not born in the current place of residence $(64.8 \%)$ and only about one-third (35.2\%) were born in current place of residence. Results on the highest educational level attained by heads of households revealed that $73.4 \%$ have at least primary level of education, while $20 \%$ have attained secondary level of education and only $6.9 \%$ have completed postsecondary education with the lowest $2.4 \%$ and $4.9 \%$ in Nessuit and Mariashoni, respectively (Table 1).

3.2. Livelihood Activities of Households. Most of the households $(90.5 \%)$ interviewed were farmers $(n=344)$ relying mostly on rain-fed agriculture and livestock keeping. Other livelihood activities were small scale retail business, wage employment, and sale of forest products. The total household income $\left(F_{(4,372)}=5.10 ; p \leq 0.001\right)$ was significantly different across study location and between indigenous and nonindigenous groups $\left(F_{(1,372)}=7.82 ; p=0.05\right)$. The total household income in 3 locations of Kapsimbeiywo, Nessuit, and Kapkembu was significantly different. However, in Kapkembu total household income differed significantly from Silibwet and Mariashoni (Table 1). Agricultural income was significantly different across locations $\left(F_{(4,382)}=2.55, p=\right.$ 0.05). Tukey B test separation of means showed that households in Kapsimbeiywo differed significantly from the households in other locations. However, agricultural household income in Silibwet, Kapkembu, Nessuit, and Mariashoni was not significantly different. In addition, income from sale of forest products was not significantly different across location $\left(F_{(4,72)}=1.23 ; p=0.05\right)$ and between indigenous and nonindigenous groups $\left(F_{(1,75)}=1.62 ; p=0.05\right)$.

\subsection{Assets}

3.3.1. Livestock. Livestock keeping is an important economic activity undertaken by households. The average number of cattle, sheep, goats, donkeys, and hens was 5.0, 4.0, 2.0, 1.0, and 7.0, respectively, and the mean Tropical Livestock Unit (TLU) per household was 4.65 units. Total livestock units per household across locations were significantly different $\left(F_{(4,367)}=11.86 ; p<0.05\right)$. Separation of means by Tukey B test showed that TLU for households in Nessuit (Mean $=3.49$, standard deviation $(\mathrm{SD})=2.81$ and Kapsimbeiywo (Mean $=$ $6.33, \mathrm{SD}=2.60)$ ) were significantly different. However, households in 3 locations of Sililbwet (Mean $=4.99, \mathrm{SD}=$ $1.84)$, Kapkembu $($ Mean $=5.02, \mathrm{SD}=1.71)$ and Marioshion (Mean $=5.10, \mathrm{SD}=2.46$ ) were not significantly different in livestock units. Wealth group differed significantly in total livestock units $\left(F_{(2,367)}=8.06 ; p<0.05\right)$. Separation of means by Tukey $\mathrm{B}$ test showed that the poor households (Mean = $3.85, \mathrm{SD}=2.78$ ) differed significantly from moderately poor $($ Mean $=5.23, \mathrm{SD}=2.41)$ and rich households $($ Mean $=4.76$, $\mathrm{SD}=2.54)$ in livestock holdings. Additionally, livestock holding (TLU) for indigenous and non-indigenous groups were not significantly different $\left(F_{(1,367)}=0.410, p>0.05\right)$.

3.3.2. Land. Most households in the study area allocate their land use to crops (both cash and food). Between 52\% and $74 \%$ of the land holding is allocated for agricultural crops and less than $21 \%(14.2 \%-21 \%)$ was allocated to forest resources (planted or natural regeneration) (Table 1). Total land size, land under cash crops, and pasture were significantly different; however land under forests (planted and natural), food crops, and wastelands were not significantly different (Table 1). The ownership of land differs across locations with highest number of households indicating alternative ownership of land was highest in Kapsimbeiywo (73.3\%) and least in Nessuit (4.0\%). There was a strong association between alternative land ownership and location $\left(\chi^{2}=118.65, \mathrm{df}=4\right.$, $p<0.001)$.

\subsection{Forest Use and Dependence}

3.4.1. Sources of Forest Products. Diverse forest products were collected by households for home consumption and for sale (Table 2). Generally most of the products were obtained from public forest of East Mau forest. For example, most households reportedly obtained their firewood and charcoal from public forest compared to the other sources $(72.9 \%$ and $67.3 \%$, resp.) and this was similarly observed for all products (Table 2).

Households obtained foods products such as indigenous fruits $(34.0 \%)$, mushrooms $(49.3 \%)$, game meat $(47.1 \%)$, and honey $(51.6 \%)$ from public forest compared to other sources (own farms, neighbours, and markets). Overall, $45.5 \%$ households obtained various foods from the East Mau forest ecosystem. About fifty percent of the households obtained 


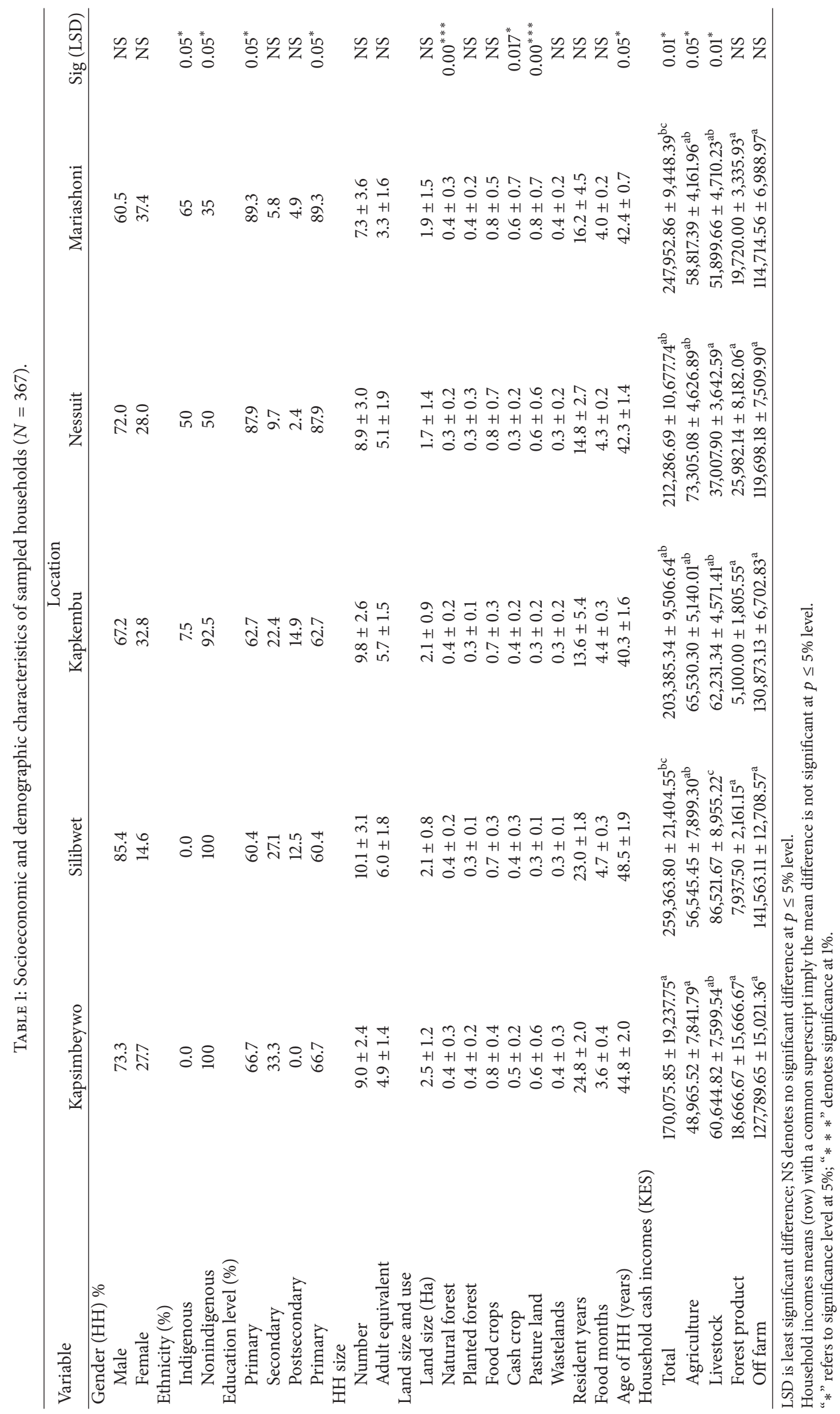


TABLE 2: Reported sources of forest products by of households $(N=$ 367).

\begin{tabular}{lcccc}
\hline \multirow{2}{*}{ Product } & \multicolumn{4}{c}{ Sources (\% households) } \\
& Public forest & Own farm & Neighbours & Market \\
\hline Firewood & 72.9 & 21.6 & 3.4 & 2.1 \\
Timber & 58.0 & 16.6 & 6.2 & 19.2 \\
Charcoal & 67.3 & 8.2 & 7.6 & 16.9 \\
Honey & 51.6 & 13.8 & 9.7 & 24.9 \\
Medicine & 49.9 & 18.7 & 5.0 & 26.4 \\
Poles & 35.7 & 21.7 & 14.0 & 28.6 \\
Thatch grass & 30.6 & 35.0 & 6.2 & 28.2 \\
Fruits & 34.0 & 22.3 & 9.7 & 34.0 \\
Animal fodder & 66.7 & 31.2 & 1.8 & 0.3 \\
Agricultural & 42.8 & 18.9 & 1.3 & 37.0 \\
tools & 45.2 & 21.8 & 7.3 & 25.7 \\
Forest soils & 41.2 & 20.3 & 9.3 & 29.2 \\
Building & & 14.4 & 8.1 & 28.2 \\
stones & 49.3 & 19.3 & 10.6 & 15.3 \\
Mushrooms & 54.8 & 3.6 & 2.3 & 47.0 \\
Fibres & 47.1 & & & \\
Meat & & &
\end{tabular}

medicinal herbs from public forest. In the study area, 57.0\%, $35.7 \%$, and $54.8 \%$ of households reportedly obtained construction materials (timber, poles, and fibers, resp.) from the public forest (Table 2).

3.4.2. Quantities and Value of Forest Products. The extent of use and monetary value of various products is shown in Table 3.

Most households in the study area collected firewood (90.3\%), herbal medicine $(83.3 \%)$, poles $(34.8 \%)$, and honey $(27.4 \%)$ and the least collected product was building stones (5.7\%) (Figure 2).

Firewood is the most collected product by households and each household collect an average of 122.00 backloads $(4,100.00 \mathrm{~kg})$ of firewood per year worth about KES $25,000.00$ (US\$ 280.00 ) accounting for $5.7 \%$ of forest income (Table 4). Another popular product collected by households is medicine $(83.3 \%)$ with an average of about $50 \mathrm{~kg}$ per year. However, in terms of monetary value per household charcoal, honey and poles score high. The values of these products are KES 144,156.00 (US\$ 1,601.00), 69,424.00 (US\$ 771.00), and $32,959.00$ (US\$ 366.00), respectively (Table 3 ). Household who graze their livestock in public forest ranged from 57.1\% (Kapsimbeiywo) and the highest of $77.9 \%$ of households in Mariashoni. Overall, 66.8\% of the households reported using the forest as a source of fodder for their livestock. The monetary value of this use ranged from KES 11,983.00 (US\$133.00) to $17,974.00$ (US\$200.00) per household per year. Wood fuel (firewood and charcoal) is the dominant source of forest income with a mean of $49.1 \%$ of forest income per household and this was followed by food products (26.5\%) and structural

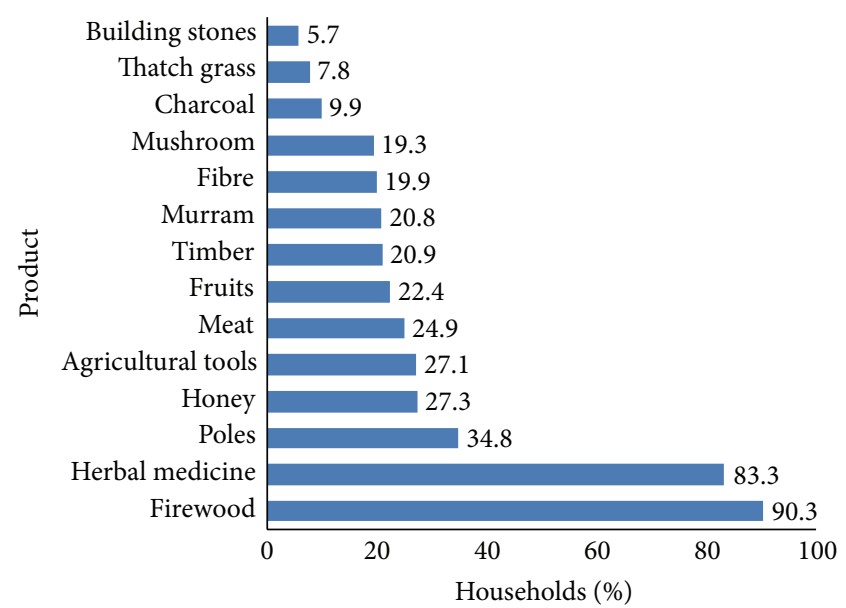

Figure 2: Proportion of households (\%) collecting various forest products from East Mau forest.

and fibre products (17.4\%). Though charcoal is not the most collected products $(9.9 \%)$ of households yet its contribution was significant contributing $43.4 \%$ to household forest income due its high value. Other products which made significant contribution to household forest income were poles and honey each contributing $13.0 \%$ and $12.4 \%$, respectively. The total forest income ranged from $28.8 \%$ to $36.5 \%$ with overall mean of $32.5 \%$ (Table 4 ).

3.4.3. Forest Dependence. The households in East Mau are dependent on East Mau forest for various products and services.

The net forest income and relative forest income are summarized in Table 5 . The forest dependence was calculated as the ratio of total forest environmental income to the total household income and expressed as a percentage. The level of dependence was greater than $25 \%$ in all study locations, ranging from $28.8 \%$ to $36.5 \%$ with overall mean of $33.7 \%$ (Table 5 ). The absolute forest income and relative forest income were not significantly different between households in the five study locations.

Absolute forest income and relative forest income (\%) were not significantly different across study locations $\left(F_{(4,309)}=1.76 ; p>0.05\right)$ and between ethnic groups $\left(F_{(1,245)}=0.307, p>0.05\right)$. However, absolute forest income and relative forest income (\%) were significantly different among wealth classes $(p<0.01)$, meaning there is substantial difference in absolute forest income (Poor $=46,275.90 \pm$ 2,822.40, Moderate household $=67,277.30 \pm 3,932.40$ and Rich household $=81,463.80 \pm 3,797.70)$ and relative forest income $(\%)$ (Poor $=41.40 \pm 2.13$, Moderate household $=35.60$ \pm 2.03 and Rich household $=26.30 \pm 1.30$ ). The Poor households benefit less in absolute terms from the forest resources than the Moderate and the Rich (Table 5) (Poor $<$ Moderate $<$ Rich). However, in relative terms (\% forest income) the poor derive more than the two categories (Poor $>$ Moderate $>$ Rich) (Table 5). 
TABLE 3: Quantities and monetary value of forest products collected by households per year.

\begin{tabular}{|c|c|c|c|c|}
\hline \multirow{2}{*}{ Product } & \multirow{2}{*}{ Units } & \multirow{2}{*}{ Quantities } & \multicolumn{2}{|c|}{ Value } \\
\hline & & & (KES) & (US\$) \\
\hline Firewood & $\mathrm{kg}$ & $4,070.45 \pm 167.67$ & $25,447.47 \pm 1104.60$ & $282.75 \pm 12.27$ \\
\hline Herbal Medicine & $\mathrm{kg}$ & $48.78 \pm 2.69$ & $7,677.09 \pm 1781.22$ & $85.30 \pm 19.79$ \\
\hline Poles & Number & $343.22 \pm 17.62$ & $32,959.22 \pm 1855.49$ & $366.21 \pm 20.62$ \\
\hline Honey & $\mathrm{kg}$ & $102.39 \pm 16.95$ & $69,424.33 \pm 5301.33$ & $771.38 \pm 58.90$ \\
\hline Agricultural tools & Number & $104.73 \pm 17.50$ & $1,053.82 \pm 174.60$ & $11.71 \pm 1.94$ \\
\hline Meat & $\mathrm{kg}$ & $125.24 \pm 12.84$ & $12,919.20 \pm 1502.18$ & $143.55 \pm 16.69$ \\
\hline Fruits & $\mathrm{Kg}$ & $256.68 \pm 23.44$ & $9,573.34 \pm 552.13$ & $106.37 \pm 6.13$ \\
\hline Timber & Running feet & $171.38 \pm 18.46$ & $18,292.06 \pm 1963.06$ & $203.25 \pm 21.81$ \\
\hline Murram & Tons & $120.22 \pm 38.21$ & $102.18 \pm 32.48$ & $1.14 \pm 0.36$ \\
\hline Fibre & $\mathrm{kg}$ & $251.77 \pm 38.98$ & $4,227.20 \pm 383.12$ & $46.97 \pm 4.26$ \\
\hline Mushroom & $\mathrm{kg}$ & $257.92 \pm 45.98$ & $3,021.28 \pm 467.80$ & $33.57 \pm 5.20$ \\
\hline Charcoal & $\mathrm{kg}$ & $4,505.55 \pm 1103.20$ & $144,156.77 \pm 22375.53$ & $1,601.74 \pm 248.62$ \\
\hline Thatch grass & $\mathrm{kg}$ & $179.08 \pm 27.80$ & $4,530.72 \pm 7,142.99$ & $50.34 \pm 79.37$ \\
\hline Building stones & Running feet & $34.50 \pm 4.20$ & $1,000.00 \pm 656.05$ & $282.75 \pm 7.29$ \\
\hline
\end{tabular}

Values are arranged as means, followed by standard error of means.

TABLE 4: Contribution of forest products category to forest income.

\begin{tabular}{|c|c|c|c|c|c|c|}
\hline \multirow{2}{*}{ Product } & \multicolumn{6}{|c|}{ Location } \\
\hline & Kapsimbeiywo & Silibwet & Kapkembu & Nessuit & Mariashoni & Mean \\
\hline Fuel & 17.20 & 59.80 & 50.30 & 51.40 & 66.90 & 49.10 \\
\hline Firewood & 10.80 & 3.90 & 5.10 & 4.40 & 4.10 & 5.70 \\
\hline Charcoal & 6.40 & 55.90 & 45.10 & 47.00 & 62.90 & 43.40 \\
\hline Food & 26.60 & 28.30 & 28.70 & 29.00 & 19.70 & 26.50 \\
\hline Fruits & 1.00 & 3.10 & 2.80 & 1.90 & 1.90 & 2.10 \\
\hline Honey & 9.40 & 15.50 & 13.40 & 13.90 & 10.00 & 12.40 \\
\hline Mushroom & 14.10 & 7.60 & 10.00 & 8.40 & 5.50 & 9.10 \\
\hline Meat & 2.00 & 2.00 & 2.60 & 4.80 & 2.30 & 2.70 \\
\hline Structural and fibre & 46.00 & 7.10 & 14.40 & 11.80 & 7.40 & 17.40 \\
\hline Timber & 6.40 & 2.70 & 5.40 & 4.00 & 2.10 & 4.10 \\
\hline Poles & 39.40 & 4.30 & 8.50 & 7.60 & 5.00 & 13.00 \\
\hline Agricultural tools & 0.20 & 0.10 & 0.60 & 0.30 & 0.20 & 0.30 \\
\hline Grass & 7.60 & 3.80 & 4.60 & 5.10 & 4.60 & 5.10 \\
\hline Thatch grass & 1.10 & 1.10 & 0.80 & 2.00 & 2.80 & 1.60 \\
\hline Fodder & 6.50 & 2.70 & 3.70 & 3.10 & 1.80 & 3.60 \\
\hline Herbal medicine & 2.60 & 0.90 & 2.00 & 2.60 & 1.20 & 1.90 \\
\hline Others & 0.00 & 0.10 & 0.00 & 0.00 & 0.20 & 0.10 \\
\hline Total & 100.00 & 100.00 & 100.00 & 100.00 & 100.00 & 100.00 \\
\hline$\%$ of total household income & 28.80 & 30.70 & 32.90 & 36.50 & 33.40 & 32.50 \\
\hline Absolute value (KES) & $47,662.00$ & $63,427.00$ & $65,218.00$ & $66,580.00$ & $71,642.00$ & $62,906.00$ \\
\hline Absolute value (US\$) & 530.00 & 705.00 & 725.00 & 740.00 & 796.00 & 699.00 \\
\hline
\end{tabular}

\subsection{Discussions}

3.5.1. Socioeconomic and Demographic Characteristics. The average family size in the study areas of $(8.8 \pm 3.2)$ is higher than national average of 5.3 persons per households [12]. However, households in Mariashoni showed lower family size. Male headed households were dominant in the study locations and this is consistent with customs of the local people where males are expected to be the heads of households and only females attain this role through bereavement. It was established that there was significant variation in asset endowment (land, physical assets, and livestock) between male and female headed households. Because crop farming and livestock are main livelihood activities in the study area ownership and access to land is one of the key determinants of livelihood options of the local people. On average, households 
TABLE 5: Absolute forest income, relative forest income (\%) by study location, wealth status, and ethnicity.

\begin{tabular}{|c|c|c|}
\hline Variable & Absolute forest income (KES) & Relative forest income (\%) \\
\hline \multicolumn{3}{|l|}{ Location } \\
\hline Kapsimbeiywo & $47,662.10 \pm 6,236.81^{\mathrm{a}}$ & $28.85 \pm 3.70^{\mathrm{a}}$ \\
\hline Silibwet & $63,427.11 \pm 6,470.64^{\mathrm{a}}$ & $30.71 \pm 3.34^{\mathrm{a}}$ \\
\hline Kapkembu & $65,217.56 \pm 4,801.03^{\mathrm{a}}$ & $32.89 \pm 2.18^{\mathrm{a}}$ \\
\hline Nessuit & $66,579.73 \pm 3,762.37^{\mathrm{a}}$ & $36.46 \pm 1.84^{\mathrm{a}}$ \\
\hline Mariashoni & $71,641.51 \pm 4,711.57^{\mathrm{a}}$ & $33.42 \pm 2.40^{\mathrm{a}}$ \\
\hline \multirow[t]{2}{*}{ Overall mean } & $65,836.28 \pm 2,232.06$ & $33.73 \pm 1.10$ \\
\hline & $\left(F_{(4,309)}=1.76, p>0.05\right)$ & $\left(F_{(4,294)}=1.18, p>0.05\right)$ \\
\hline \multicolumn{3}{|l|}{ Wealth status } \\
\hline Poor & $46,275.90 \pm 2,822.40^{\mathrm{a}}$ & $41.40 \pm 2.13^{\mathrm{a}}$ \\
\hline Moderate & $67,277.30 \pm 3,932.40^{\mathrm{b}}$ & $35.60 \pm 2.03^{\mathrm{b}}$ \\
\hline \multirow[t]{2}{*}{ Rich } & $81,463.80 \pm 3,797.70^{c}$ & $26.30 \pm 1.30^{c}$ \\
\hline & $\left(F_{(2,309)}=23.87, p<0.01\right)$ & $\left(F_{(2,296)}=18.35, p<0.01\right)$ \\
\hline \multicolumn{3}{|l|}{ Ethnicity } \\
\hline Indigenous & $63,536.12 \pm 3,961.22^{\mathrm{a}}$ & $31.93 \pm 1.75^{\mathrm{a}}$ \\
\hline \multirow[t]{2}{*}{ Nonindigenous } & $62,658.47 \pm 2,196.54^{\mathrm{a}}$ & $33.15 \pm 1.25^{\mathrm{a}}$ \\
\hline & $\left(F_{(1,241)}=0.74, p>0.05\right)$ & $\left(F_{(1,245)}=0.307, p>0.05\right)$ \\
\hline
\end{tabular}

Note. Means (column) with a common (letters) superscript imply the mean difference is not significant different at $p \leq 5 \%$ level.

in Nessuit and Mariashoni have less land compared to households in other locations.

Most of the study areas (Mariashoni, Nessuit, and Kapkembu) were once part of East Mau forest. However, they were excised in 1990s and early 2000 for human settlement [7]. Each household in the settlement scheme was allocated 2.5 ha. The results showed that households in Nessuit and Mariashoni currently have smaller land size than originally allocated. This is most likely due to land transactions which might have occurred in the two locations. This finding was corroborated by key informants who reported increased number of new settlers due to high productivity of the land for food and cash crops. This fact was also reflected in the heterogeneity of the local population showed by household data which showed that most of the household heads (64.8\%) were not indigenous to current place of residence. Households in Kapsimbeiywo have the highest access to land and this is reflected in the fact that about $78 \%$ of households have alternative access to land. This phenomenon of emigration from other areas in search of land and livelihood opportunities conforms to what has been established in other African societies where migration is influenced by demographic trends and the search for livelihood opportunities [16].

Households in the study area have adapted a diverse portfolio of livelihood activities such as farming, livestock keeping, forest product, small trade and remittance. The most common livelihood activity is farming and livestock keeping.

The local indigenous communities, the Ogiek have largely depended on livestock and forest resources. This is, however, changing due to the growing influence of immigrants from other counties. There is evidence of increasing diversification of income opportunities by the indigenous community. This is consistent with other studies on rural communities where livelihood diversification strategies is predominant [17-19] because single livelihood strategy is insufficient for the needs of most rural households [20]. There was a strong association between educational attainment and ethnicity $\left(\chi^{2}=3.49\right.$, $\mathrm{df}=2, p<0.05)$.

The household heads of nonindigenous group had higher postsecondary qualifications compared to indigenous households. Mariashoni and Nessuit dominated by Ogiek community had fewer schools. Livestock size (TLU) in the study area showed significant results pointing to the fact that the ownership of large herds is associated with access to alternative land. The households which had alternative land also showed large livestock size and lowest forest grazing incidence. Forest grazing is dependent on seasonal availability of fodder on the farms and forest grazing is an alternative resource. The implication is that alternative land ownership accounts for the additional livestock units owned.

3.5.2. Forest Dependence. The result from this study has shown that local people depend primarily on forest resources for subsistence needs and occasionally for sale. The highest contribution to household forest income is fuel wood $(50 \%)$ and food products $(27 \%)$. The high market value from fuel wood use category could be explained by the significantly high level of firewood collection by majority of households $(90.3 \%)$ and the relatively high value of charcoal.

The study has revealed that forest income contributes between $25 \%$ and $36.5 \%$ of household income in the study area. This could be explained by low level of investment in tree growing and less retention of natural forests on individual farms and ease of access to public resources. The findings on forest reliance confirm what others have concluded in other parts of Africa, for example, Cavendish [21], found out that $35 \%$ of rural household income is derived from environmental products in Zimbabwe. Another study in Malawi showed 
that forest income contributes to $30 \%$ of household income [22]. Forest income contributes about 39\% of the household income in Ethiopia highlands and nearly equaled combined livestock and agricultural incomes [23].

Another study by Kalaba et al. [24] in Miombo woodlands of Zambia showed that forest income contributed $43.9 \%$ to the average household income. In a compressive comparative analysis of environmental income, Angelsen et al. [25] revealed that environmental income accounted for $28 \%$ of household income in 24 developing countries. Therefore the findings of this study are in agreement with similar findings elsewhere and corroborate the importance of forest resources to households. In terms of who benefits more from forest resources, the moderately poor and higher income households derive higher absolute forest income than poor households. This is probably because the rich households extract high value products such as timber, poles which require large capital investments such as equipment which are inaccessible by poor households and therefore primarily engaged in low value and often labour intensive forest extractive activities [26]. Limited access to financial and social capital has been advanced by various authors $[25,27]$ to explain the inability of the poor households to benefit substantially from environmental resources. However, in relative forest income, poor households showed higher reliance on forest resources. These findings on the higher dependency on forest resources by poor households are consistent with findings of $[16,19,23,28-$ 32].

\section{Conclusion and Recommendations}

The study has revealed the important role of forest resources in household income. It was found out that forest income share are higher for poor households. However, in absolute terms, the better off households are advantaged. Poor households showed high dependence on the forest resources despite most collection/usage being illegal. On average $33 \%$ of annual household income is generated by consumption and sale of forest products. With the increasing population in East Mau and surrounding areas, the demand on forest resources are likely to rise and this will exert pressure on the state of forest resources in East Mau. However, reflecting on the findings of this study, it would be imprudent to exclude local community from accessing forest resources because; it may lead to increased poverty. One way of managing the situation would be to allow low level extractive activities such as firewood collection and enforcing licensing procedures to allow for low extraction level, essentially for subsistence use and discourage commercial extraction. Another way to ease the pressure on East Mau is to promote intensification of tree growing on farms through support for agroforestry or farm forestry intervention. Another strategy is to lower the opportunity cost of engaging in forest resources by creating robust income opportunities independent of forest product extraction or improving the technical efficiency of agricultural and production systems in order to minimize illegal forest exploitation. These measures may improve rural livelihoods and conserve forest resources and biodiversity.

\section{Appendix}

\section{Estimation of the Value Forest Grazing}

According to the household data livestock data the mean livestock numbers 4.9 livestock units and $67 \%$ of households graze their animals inside the forest and forest fodder/browse make up to $40 \%$ of the fodder requirements. From literature, the dry fodder requirement for livestock is taken to be about $2-3 \%$ of the body weight per day [33] and a livestock unit $(250 \mathrm{~kg})$ requires a minimum quantity of fodder for maintenance of between 5.0 and $7.5 \mathrm{~kg}$ per day.

Step 1. Calculate the number of households who graze their animals $=(43,527 * 67) / 100=29,163.00$.

Step 2. Calculate the total number of livestock units grazing inside the forest $=29163 * 4.9=142,898.00$.

Step 3. Calculate the total dry matter requirements for the total livestock units for the whole year from the forest.

One TLU requires between 5.0 and $7.5 \mathrm{~kg}$ per day; therefore 365 days $=142,898 *(5.0-7.5) * 365$.

The total dry matter requirements per year is between $260,788.85$ and $391,183.28 \mathrm{~kg}$.

$40 \%$ of the total fodder requirements are obtained from the forest and therefore forest contributes between 104,315.54 and $156,473.31 \mathrm{~kg}$.

Step 4. Convert the estimate quantities of dry matter into Hay equivalent.

One bale of hay weighs $30 \mathrm{kgs}$; the number of equivalent hay is between $3,477.20$ and 5,215.80 bales.

Step 5. Calculate the monetary value of hay using the current market price. The current market price of 1 bale is KES 150 .

The total value of forest grazing is KES 521,577.75 and $782,366.55$ per year. This is equivalent to between KES $11,983.00$ and 17,974.00 per household per year.

\section{Ethical Approval}

Ethical issues (including plagiarism, informed consent, misconduct, data fabrication and/or falsification, double publication, and redundancy) have been completely observed by the authors.

\section{Conflict of Interests}

The authors declare that there is no conflict of interests regarding the publication of this paper.

\section{Acknowledgments}

The authors express their gratitude to East Mau community for their willingness to share with us their information on forest use. Special thanks are due to research assistants and local administrative officials in the study areas for their support during data collection. Special thanks are due to $\mathrm{Mr}$. Frank Mairura for assisting in data analysis. The authors are 
grateful to the Director Kenya Forestry Research Institute for financially supporting this study.

\section{References}

[1] S. Chao, Forest People: Numbers across the World, Forest Peoples Program, Moreton-in-Marsh, UK, 2012.

[2] World Bank, Global Issues for Global Citizens: An Introduction to Key Development Challenges, Edited by V. K. Bhargava, The World Bank Report, Washington, DC, USA, 2006.

[3] P. Vedeld, A. Angelsen, J. Bojö, E. Sjaastad, and G. K. Berg, "Forest environmental incomes and the rural poor," Forest Policy and Economics, vol. 9, no. 7, pp. 869-879, 2007.

[4] C. Shackleton and S. Shackleton, "The importance of nontimber forest products in rural livelihood security and as safety nets: a review of evidence from South Africa," South African Journal of Science, vol. 100, no. 11-12, pp. 658-664, 2004.

[5] C. M. Shackleton and S. E. Shackleton, "Household wealth status and natural resource use in the Kat River valley, South Africa," Ecological Economics, vol. 57, no. 2, pp. 306-317, 2006.

[6] J. K. Sang, "The Ogiek in Mau Forest: Case Study 3-KenyaForest Peoples Program, 2001," http://www.forestpeoples.org/ sites/fpp/files/publication/2010/10/kenyaeng.pdf.

[7] UNEP, KFWG, DRSRS, and EU-BCP, Eastern and South Western Mau Forests Reserves: Assessment and Way Forward, UNEP, Nairobi, Kenya, 2006.

[8] W. G. Sombroek, H. M. Braun, and B. J. Van der Pouw, "The Exploratory soil map and agro-climatic map of Kenya," Report E 1, Kenya Soil Survey, Nairobi, Kenya, 1980.

[9] S. S. China, Land use planning using GIS [Ph.D. thesis], University of Southampton, Southampton, UK, 1993.

[10] R. Jaetzold and H. Schmidt, Farm Management Handbook for Kenya, Ministry of Agriculture, Nairobi, Kenya, 1982.

[11] P. M. Kundu, Application of remote sensing and GIS techniques to evaluate the impact of land use cover change on stream flows: the case of River Njoro in Eastern Mau-Kenya [Ph.D. thesis], Faculty of Environment and Resources Development, Egerton University, Njoro, Kenya, 2007.

[12] KNBS, Kenya Population and Housing Census, vol. 1A, Ministry of Planning and National Development, Nairobi, Kenya, 2010.

[13] O. Mugenda and A. Mugenda, Research Methods Quantitative and Qualitative Approaches, African Center for Technology Studies (ACTS), Nairobi, Kenya, 1999.

[14] B. M. Campbell and M. Luckert, "Towards understanding the role of forests in rural livelihoods," in Uncovering the Hidden Harvest: Valuation Methods for Woodland and Forest Resources, B. M. Campbell and M. K. Luckert, Eds., People and Plants Conservation Series, pp. 1-10, Earthscan, London, UK, 2002.

[15] Y. H. Chan, "Biostatistics 102: quantitative data-parametric and non-parametric tests," Singapore Medical Journal, vol. 44, no. 8, pp. 391-396, 2005.

[16] K. Heubach, The socio-economic importance of non-timber forest products for rural livelihoods in West African savanna ecosystems: current status and future trends [Ph.D. thesis], Goethe Universität Frankfurt, Frankfurt, Germany, 2011.

[17] B. Belcher, M. Ruíz-Pérez, and R. Achdiawan, "Global patterns and trends in the use and management of commercial NTFPs: implications for livelihoods and conservation," World Development, vol. 33, no. 9, pp. 1435-1452, 2005.

[18] F. Ellis, Rural Livelihoods and Diversity in Developing Countries, Oxford University Press, Oxford, UK, 2000.
[19] P. Kamanga, P. Vedeld, and E. Sjaastad, "Forest incomes and rural livelihoods in Chiradzulu District, Malawi," Ecological Economics, vol. 68, no. 3, pp. 613-624, 2009.

[20] W. D. Sunderlin, A. Angelsen, B. Belcher et al., "Livelihoods, forests, and conservation in developing countries: an overview," World Development, vol. 33, no. 9, pp. 1383-1402, 2005.

[21] W. Cavendish, "Poverty, inequality and environmental resources: quantitative analysis of rural households," Centre for the Study of African Economies (CSAE) Paper Series, Paper 93, 1999.

[22] M. Fisher, "Household welfare and forest dependence," Environment and Development Economics, vol. 9, no. 2, pp. 135-154, 2004.

[23] G. Mamo, E. Sjaastad, and P. Vedeld, "Economic dependence on forest resources: a case from Dendi District, Ethiopia," Forest Policy and Economics, vol. 9, no. 8, pp. 916-927, 2007.

[24] F. K. Kalaba, C. H. Quinn, and A. J. Dougill, "Contribution of forest provisioning ecosystem services to rural livelihoods in the Miombo woodlands of Zambia," Population and Environment, vol. 35, no. 2, pp. 159-182, 2013.

[25] A. Angelsen, P. Jagger, R. Babigumira et al., "Environmental income and rural livelihoods: a global-comparative analysis," World Development, vol. 64, no. 1, pp. S12-S28, 2014.

[26] M. Arnold and I. Townson, "Assessing the potential of forest product activities to contribute to rural incomes in Africa," Natural Resources Perspectives 37, Overseas Development Institute, London, UK, 1998.

[27] S. Dewi, B. Belcher, and A. Puntodewo, "Village economic opportunity, forest dependence, and rural livelihoods in East Kalimantan, Indonesia," World Development, vol. 33, no. 9, pp. 1419-1434, 2005.

[28] A. Angelsen and S. Wunder, "Exploring the forestry-poverty linkage: key concepts, issues and research implications," CIFOR Occasional Paper 40, CIFOR, Bogor, Indonesia, 2003.

[29] B. Babulo, Economic Valuation and Management of CommonPool Resources: The Case of Enclosures in the Highlands of Tigray, Northern Ethiopia, vol. 762 of Doctoraatsproefschrift, Faculteit Bio-Ingenieurswetenschappen Van de K.U. Leuven, 2007.

[30] W. Cavendish, "Empirical regularities in the povertyenvironment relationship of rural households: evidence from Zimbabwe," World Development, vol. 28, no. 11, pp. 1979-2003, 2000.

[31] P. Illukpitiya and J. F. Yanagida, "Farming vs forests: trade-off between agriculture and the extraction of non-timber forest products," Ecological Economics, vol. 69, no. 10, pp. 1952-1963, 2010.

[32] J. K. Mariara and C. Gachoki, "Forest dependence and household welfare: empirical evidence from Kenya," CEEPA Discussion Paper 41, CEEPA, 2008.

[33] B. Ganesan, "Extraction of non-timber forest products, including fodder and fuelwood, in Mudumalai, India," Economic Botany, vol. 47, no. 3, pp. 268-274, 1993. 

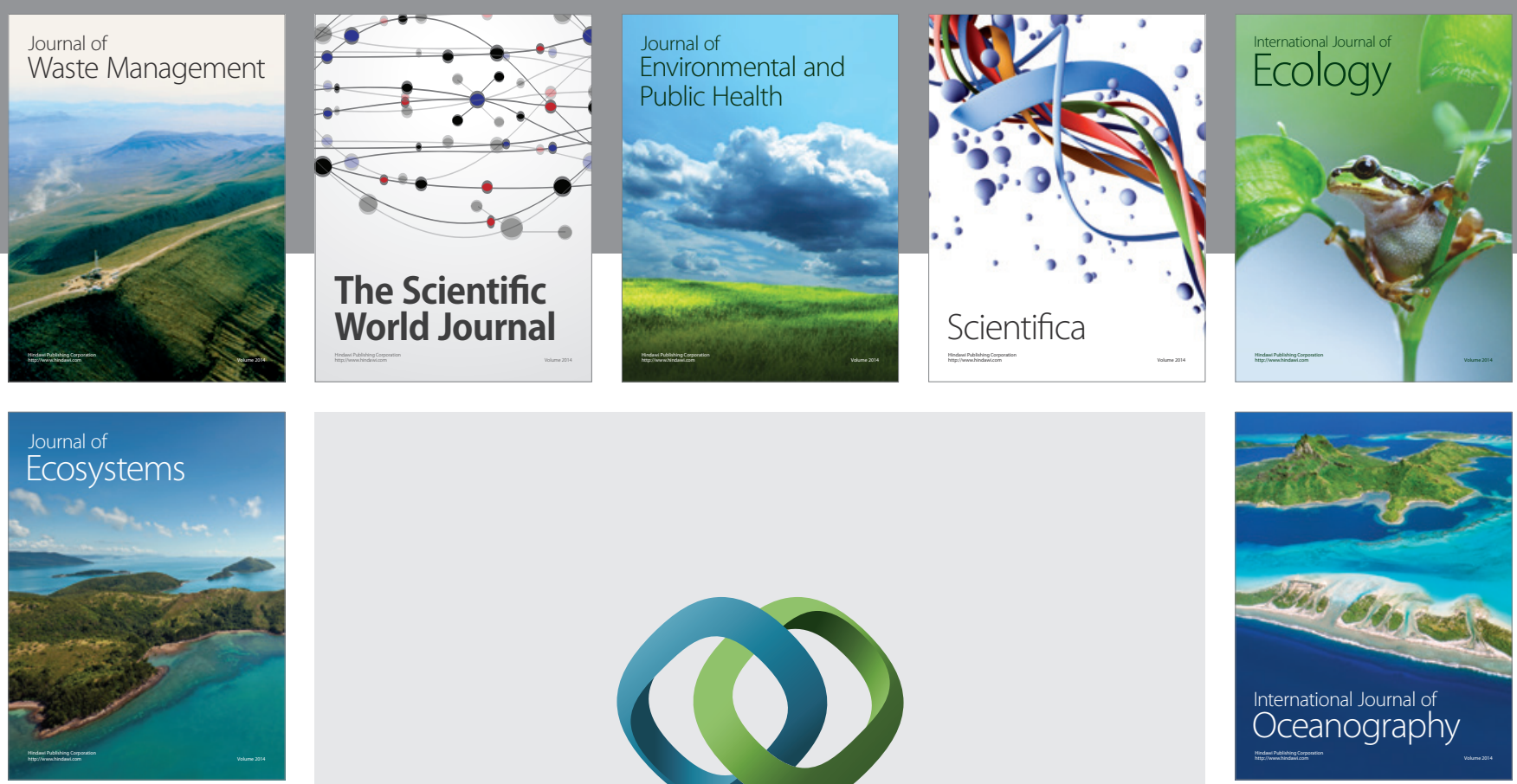

The Scientific World Journal
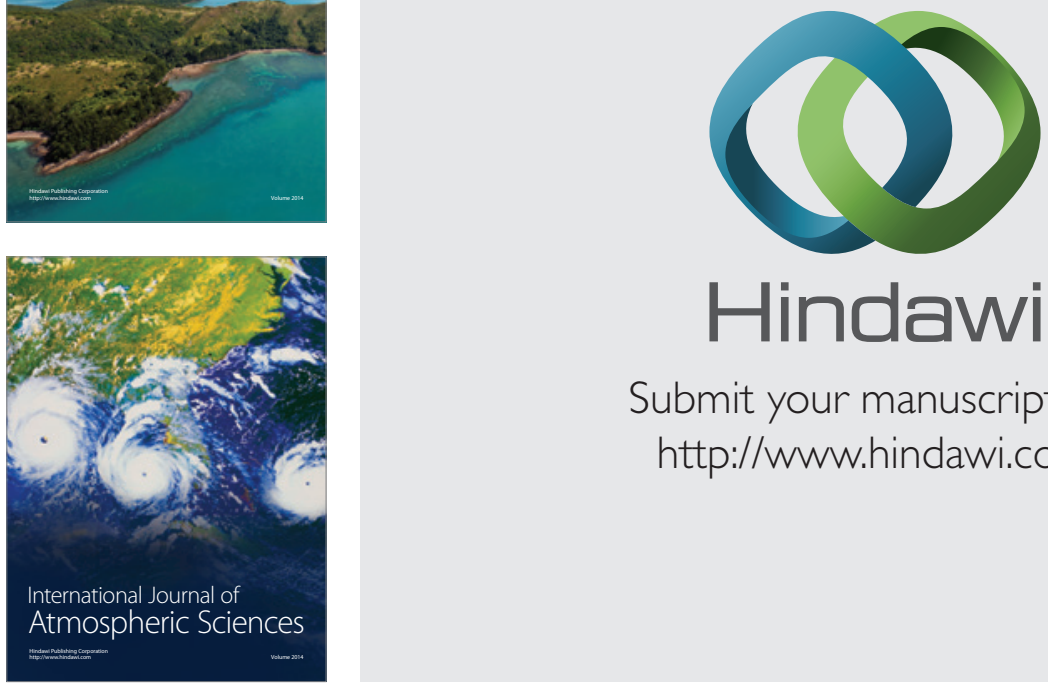

\section{Hindawi}

Submit your manuscripts at

http://www.hindawi.com
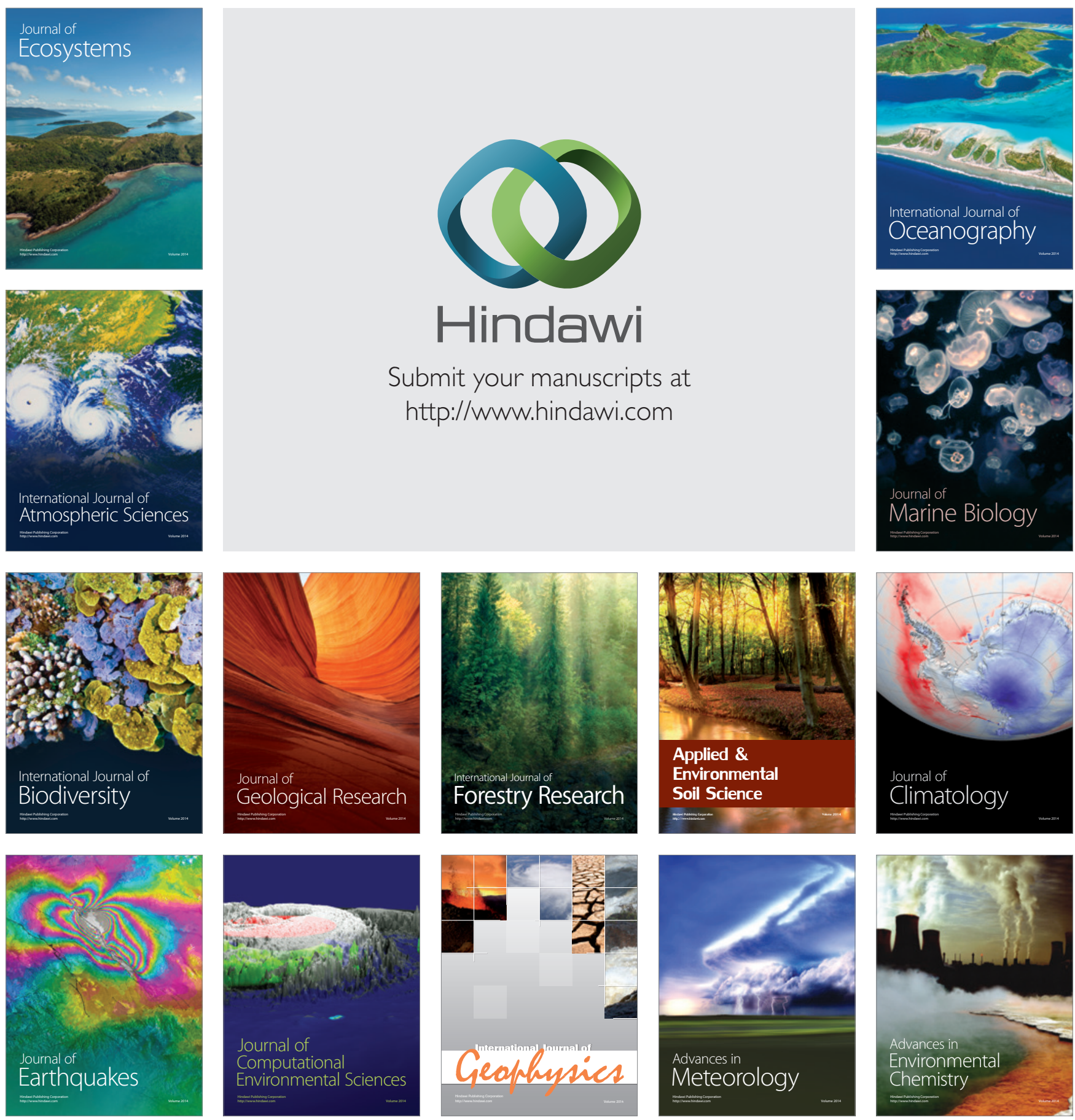